\title{
ANALISIS PENGEMBANGAN OBJEK WISATA UNTUK MENINGKATKAN KUNJUNGAN WISATAWAN PADA TAMAN MARGASATWA DAN BUDAYA KINANTAN KOTA BUKITTINGGI PROVINSI SUMATERA BARAT
}

\author{
DEWI ANGGRAINI, VINA KUMALA
}

Universitas Muhammadiyah Sumatera Barat dewianggraini2606@gmail.com,vinakumala17@gmail.com

\begin{abstract}
The city of Bukittinggi as one of the largest tourist cities in West Sumatra has a leading tourist attraction which is one of the oldest zoos in Indonesia. This zoo also displays various Minangkabau cultural attractions, therefore the government named this zoo Kinantan Wildlife and Culture Park (Taman Margasatwa dan Budaya Kinantan). Based on preliminary observations, data shows that the number of tourist visits to Kinantan is not proportional to the level of tourist visits to the City of Bukittinggi. Therefore, an in-depth research is carried out on the development of facilities and the role of the government in that development. This study uses descriptive qualitative methods, with data collection techniques through observation, interviews, and documentation. The results showed that the analysis showed that the role of government in developing Kinantan, namely as a motivator, facilitator, and dynamist has been running well and can increase the number of tourist visits.
\end{abstract}

Keyword: Tourism Facilities, Role of Government, Tourism Development

Abstrak: Kota Bukittinggi sebagai kota pariwisata terbesar di Sumatera Barat, memiliki objek wisata unggulan yang merupakan salah satu kebun binatang tertua di Indonesia. Kebun binatang ini juga menampilkan berbagai atraksi budaya Minangkabau, oleh karena itu pemerintah memberi nama kebun binatang ini Taman Margasatwa dan Budaya Kinantan. Berdasarkan observasi awal didapatkan data bahwa jumlah kunjungan wisatawan ke Kinantan tidak sebanding dengan tingkat kunjungan wisatawan ke Kota Bukittinggi. Oleh karena itu dilakukan penelitian mendalam pada pengembangan fasilitas dan peran pemerintah dalam pengembangan tersebut. Penelitian ini menggunakan metode kualitatif deskriptif, dengan teknik pengumpulan data melalui observasi, wawancara, dan dokumentasi. Pada hasil penelitian didapatkan analisis bahwa peran pemerintah dalam pengembangan Taman Margasatwa dan Budaya Kinantan yaitu sebagai motivator, fasilitator, dan dinamisator sudah berjalan dengan baik dan dapat meningkatkan jumlah kunjungan wisatawan.

Kata Kunci: Fasilitas Pariwista, Peran Pemerintah, Pengembangan Pariwisata.

\section{A. Pendahuluan}

Taman margasatwa atau lebih dikenal dengan kebun binatang, adalah salah satu destinasi wisata yang menampilkan beragam atraksi hewan. Tempat ini memelihara beraneka ragam jenis hewan dengan latar lingkungan buatan yang pengelolaannya harus diatur sesuai regulasi yang telah ditetapkan pemerintah. Sebagai destinasi, taman margasatwa juga bisa berfungsi sebagai tempat wisata pendidikan, penelitian, dan wadah konservasi satwa yang terancam punah.

Kota Bukittinggi yang merupakan salah satu kota tujuan wisata yang terdapat di Provinsi Sumatera Barat, juga memiliki kebun binatang yang bernama Taman Margasatwa dan Budaya Kinantan. Taman ini dikelola oleh Dinas Pariwisata, Pemuda dan Olahraga (Disparpora) yang terus memberi berbagai dukungan untuk mengembangkan sarana dan prasarana wisata. 
Pengembangan dan pemeliharaan sebuah objek wisata tentunya memerlukan strategi dan manajemen yang profesional dan berkelanjutan, agar tercipta sinergi yang harmonis antara wisatawan, masyarakat, dan stakeholders, sehingga tercapai tujuan utama pariwisata itu sendiri, yaitu peningkatan kunjungan wisata dan peningkatan ekonomi daerah. Taman Margasatwa dan Budaya Kinantan memiliki lokasi yang sangat strategis dan mudah dijangkau, yaitu berjarak 150 meter dari pusat kota sehingga dapat ditempuh dengan berjalan kaki.

Taman Margasatwa dan Budaya Kinantan juga menawarkan beragam atraksi wisata yang menarik, seperti berbagai jenis hewan, rumah adat yang memamerkan berbagai artefak kebudayaan Minangkabau, Jembatan Limpapeh, taman-taman hijau yang dilengkapi tempat duduk untuk bersantai, pusat kebudayaan, Benteng Ford De Kock, dan spot-spot foto yang instagramable. Berdasarkan data tahun 2016 sampai 2018, terlihat bahwa Taman Margasatwa dan Budaya Kinantan cukup diminati oleh wisatawan mancanegara (wisman) maupun wisatawan nusantara (wisnus), data tersebut dapat dilihat pada tabel 1 berikut:

Tabel 1. Jumlah Pengunjung Taman Margasatwa dan Budaya Kinantan, Hasil Penjualan Tiket Masuk Tahun 2016-2018.

\begin{tabular}{|c|c|c|c|}
\hline Tahun & $\mathbf{2 0 1 6}$ & $\mathbf{2 0 1 7}$ & $\mathbf{2 0 1 8}$ \\
\hline Total & 700.657 & 777.376 & 818.429 \\
\hline
\end{tabular}

Sumber: Kota Bukittinggi Dalam Angka, 2019

Pada tabel 1 terlihat bahwa tingkat kunjungan wisatawan yang berkunjung ke Taman Margasatwa dan Budaya Kinantan dalam 3 (tiga) tahun terakhir mengalami kenaikan, namun tidak signifikan jika dibandingkan dengan tingkat kunjungan wisatawan ke Kota Bukittinggi yang terlihat pada tabel 2 berikut:

Tabel 2. Tingkat Kunjungan Wisatawan Ke Kota Bukittinggi Tahun 2016-2018

\begin{tabular}{|l|l|l|}
\hline Tahun & Wisman & Wisnus \\
\hline 2016 & 27.516 & 1.040 .000 \\
\hline 2017 & 30.412 & 1.010 .000 \\
\hline 2018 & 31.841 & 1.118 .319 \\
\hline
\end{tabular}

Sumber: Sumatera Barat Dalam Angka, 2019; Bukittinggi Dalam Angka, 2019

(Diolah)

Berdasarkan tabel 2, tergambarkan bahwa tingkat kunjungan wisnus dan wisman yang cukup tinggi. Berdasarkan observasi data tersebut, maka didapatkan hipotesis awal bahwa masih banyak wisatawan yang tidak tertarik untuk mengunjungi Taman Margasatwa dan Budaya Kinantan sebagai salah satu objek wisata unggulan di Kota Bukittinggi. Oleh sebab itu, diperlukan peninjauan mendalam pada pengelolaan dan pengembangan objek wisata tersebut, apakah Dinas Pariwisata, Pemuda dan Olahraga Kota Bukittinggi sebagai dinas yang bertanggung jawab sudah menjalankan sistem manajeman yang baik terhadap pemeliharaan dan pengembangan fasilitas Taman Margasatwa dan Budaya Kinantan, dan bagaimana peran tersebut dijalankan.

Pengembangan sebuah destinasi wisata adalah suatu alternatif tindakan yang diharapkan dapat mendorong ekonomi daerah dan upaya pelestarian lingkungan dengan menata ulang beragam potensi alam dan hayati secara terintegrasi dan terpadu yang berorientasi pada pelestarian lingkungan (Ramly, 2007, dalam Yustinaningrum, 2017). Dalam kasus ini Disparpora Kota Bukittinggi memiliki peran sebagai pengawas dan pengembang Taman Margasatwa dan Budaya Kinantan. 
Peran adalah suatu tindakan atau perilaku yang dilakukan individu atau kelompok dalam sebuah peristiwa. Sebuah kelompok atau organisasi harus memiliki struktur kerangka kerja dengan berbagai fungsi yang harus dijalani oleh anggotanya agar mencapai tujuan utama organisasi tersebut, sebuah organisasi bisa dikatakan telah berhasil menjalankan perannya dengan profesional jika semua tugas dan fungsinya berjalan baik (Rivai, 2003; Poerwadarminta, 1995; dalam Dimahandi, 2017).

Pengembangan potensi pariwisata suatu daerah tidak bisa lepas dari peranan pemerintah, Pitana dan Gayatri (2005) dalam Dimahandi (2017) berpendapat bahwa peran pemerintah daerah adalah sebagai: 1) Motivator, yaitu memberikan rangsangan semangat yang memotivasi para pelaku usaha pariwisata, masyarakat, dan kumunitas untuk menggerakkan usaha pariwisata; 2) Fasilitator, yaitu memfasilitasi berbagai regulasi, program, kerjasama, dan bantuan dana; 3) Dinamisator, yaitu sebagai pondasi good governance yang mensinergikan hubungan yang dinamis antara stakeholders, masyarakat, dan pelaku usaha pariwisata lainnya sehingga terjalin hubungan yang saling menguntungkan.

Fasilitas pariwisata adalah sarana prasarana yang berfungsi untuk mendukung aktifitas operasional sebuah objek pariwisata agar dapat mengakomodasi berbagai kebutuhan wisatawan. Fasilitas tidak mendorong pertumbuhan pariwisata secara langsung, namun ikut berkembang bersamaan atau setelah atraksi tersebut berkembang (Spillane, 1994 dalam Rosita, Marhanah, Wahadi, 2016). Berdasarkan teori tersebut kemudian fasilitas dikelompokakan dalam 3 (tiga) bagian yaitu: 1) Fasilitas utama, atau sarana yang benar-benar diperlukan wisatawan disebuah objek wisata; 2) Fasilitas pendukung, atau sarana pelengkap fasilitas utama yang menimbulkan rasa nyaman dan senang pada wisatawan; dan 3) Fasilitas penunjang, atau sarana pelengkap yang dapat memenuhi kebutuhan wisatawan selama berwisata (Mukhlas, 2008, dalam Rosita, Marhanah, Wahadi, 2016).

Pendapat tersebut dipertegas dalam peraturan pemerintah yang menyatakan bahwa sebuah lembaga konservasi seperti kebun binatang haruslah memiliki fasilitas seperti: 1) Fasilitas utama, yaitu kandang dan klinik hewan, serta gudang makanan; 2) Fasilitas pendukung, yaitu pusat informasi, peta lokasi dan informasi satwa, tempat penjualan karcis atau loket, dan tempat beristirahat atau duduk (shelter); dan 3) Fasilitas penunjang, yaitu toilet, petunjuk arah, tempat sampah, toko cendera mata, serta tempat-tempat pelayanan umum. (Menteri Kehutanan Republik Indonesia No. P.31/Menhut-II/2002, Pasal 9).

\section{B. Metodologi Penelitian}

Penelitian ini merupakan penelitian kualitatif dengan pendekatan deskriptif, dimana seorang peneliti bertindak dan menempatkan diri menjadi instrument kunci (Sugiyono, 2015). Data yang dihasilkan dalam penelitian kualitatif akan bersifat deskriptif, pada penelitian ini data didapatkan berdasarkan hasil wawancara, observasi lapangan, dan analisis dokumen. Alat Pengumpul data: Observasi lapangan, untuk mengumpulkan data maka pengamatan objek atau observasi dalam penelitian ini dilakukan secara langsung dan tidak langsung di Taman Margasatwa dan Budaya Kinantan, sehingga peneliti mendapatkan gambaran permasalahan untk menjawab pertanyaan penelitian. Wawancara dilakukan kepada Disparpora Kota Bukittinggi dengan cara berinteraksi dan berkomunikasi. Hal ini dilakukan dalam dua bentuk, yaitu wawancara terstruktur dengan berbagai bentuk pertanyaan sesuai variabel yang diteliti, dan wawancara tidak terstruktur atau wawancara bebas dengan melontarkan pertanyaan berdasarkan garis besar masalah penelitian, hal ini dilakukan jika jawaban E-ISSN: 2657-0300 Lembaga Penelitian dan Penerbitan Hasil Penelitian Ensiklopedia $\quad 99$ 
informan berkembang diluar pedoman penelitian. Analisis dokumen, dokumen atau dokumentasi adalah data berupa catatan sejarah, buku, laporan resmi, tulisan-tulisan yang dapat dipertanggung jawabkan orisinalitasnya, foto, prasasti, artefak, dan lain sebagainya. Sumber dokumen dalam penelitian ini berasal dari Badan Pusat Statistik (BPS) Sumatera Barat, BPS Kota Bukittinggi, pihak manajemen Taman Margasatwa dan Budaya Kinantan, dan Disparpora Kota Bukittinggi. Penelitian ini menggunakan teknik analisis data Miles dan Huberman dengan analisis interaktif. Proses yang dilakukan adalah melakukan reduksi, penyajian data, dan verifikasi atau menarik kesimpulan. Kegiatan ini dilakukan dalam waktu bersamaan yang terjadi terus menerus sebelum peneliti memasuki lapangan, selama dilapangan, dan setelah selesai dilapangan, hingga datanya jenuh. Langkah-langkah yang dilakukan dapat dijelaskan sebagai berikut: a) Reduksi data adalah proses menyeleksi, memusatkan, menyederhanakan, abstraksi, dan transformasi data-data kasar yang didapatkan dilapangan, kemudian data tersebut dikategorikan sesuai fungsinya dan diinterpretasikan dengan baik sesuai teori variabel penelitian; b) Display data, penyajian data adalah cara menampilkan suatu data dalam berbagai bentuk. Pada penelitian kualitatif penyajian data dilakukan secara naratif atau deskriptif, yaitu menggambarkan dalam bentuk tulisan hasil penelitian yang didapatkan di lapangan, yaitu Taman Margasatwa dan Budaya Kinantan dan Disparpora Kota Bukittinggi; dan c) Kesimpulan, merupakan proposisi pernyataan singkat dan sistematis dari seluruh hasil analisis, pengujian hipotesis, dan pembahasan penelitian, yang diberikan ide pemikiran atau gagasan berdasarkan aturan-aturan inferensi.

\section{Hasil dan Pembahasan}

Berdasarkan analisis data penelitian, didapatkan hasil bahwa tingkat kunjungan wisatawan sangat dipengaruhi oleh peran Disparpora Kota Bukittinggi dalam pengembangan sarana dan prasarana Taman Margasatwa dan Budaya Kinantan, hal ini dijelaskan sebagi berikut: Pertama, Disparpora melakukan peran dengan baik sebagai motivator, fasilitator, maupun dinamisator dalam pengembangan fasilitas Taman Margasatwa dan Budaya Kinantan Kota Bukittinggi. Hal ini terlihat dari anggaran dana yang diberikan Disparpora kepada Taman Margasatwa dan Budaya Kinantan untuk program mengembangkan fasilisas sarana prasarana. Disparpora juga melakukan pengawasan, mengontrol, dan menjalankan pengembangan tersebut. Anggaran dana yang dialokasikan Disparpora sangat terbatas, oleh sebab itu Disparpora melakukan kerja sama dengan stakeholders, swasta, dan masyarakat, dalam pengembangan tersebut.

Kedua, fasilitas yang telah dikembangkan oleh Diparpora dari tahun 2016 hingga tahun 2018 adalah fasilitas utama, fasilitas penunjang, dan fasilitas pendukung lainnya, antara lain perbaikan kandang gajah, pengecatan jembatan Limpapeh, menambah keragaman cendera mata dan spot foto berupa gerbang kayu dan aneka payung.

Perbaikan tersebut dilakukan sebagai bentuk usaha untuk menarik kunjungan wisatawan, kerena Disparpora sangat menyadari bahwa fasilitas wisata adalah sarana prasarana yang berperan penting sebagai pendukung operasional kepariwisataan yang dapat memenuhi kebutuhan wisatawan.

Peran Disparpora sebagai motivator, fasilitator, serta dinamisator pada pengembangan fasilitas Taman Margasatwa dan Budaya Kinantan selama tahun 2016 hingga 2018 telah berhasil meningkatkan kunjungan wisatawan sebesar 1,19\%. 


\section{Penutup}

Sesuai temuan yang didapatkan dari penelitian ini, maka dapat disimpulkan bahwa: Peran Disparpora Kota Bukittinggi dalam pengembangan fasilitas Taman Margasatwa dan Budaya Kinantan adalah sebagai berikut: a) Sebagai motivator, memberikan semangat dan berbagai saran kepada pengelola Taman Margasatwa dan Budaya Kinantan Kota Bukittinggi, bekerjasama dengan pelaku UMKM, stakeholders, dan pengusaha swasta; b) Sebagai fasilitator, mengawasi pelaksanaan pengembangan Taman Margasatwa dan Budaya Kinantan agar sesuai dengan Standar Operasional Prosedur (SOP) yang telah ditetapkan; c) sebagai dinamisator, Disparpora melakukan sinergi dengan berbagai pihak agar tercipta harmonisasi antar stakeholders yang terlibat dalam pembangunan Taman Margasatwa dan Budaya Kinantan. Berbagai fasilitas yang telah dikembangkan Disparpora di Taman Margasatwa dan Budaya Kinantan antara lain: a) fasilitas utama, perbaikan dan pemeliharaan gudang makanan, kandang Gajah, dan pagar pembatas pada kandang Burung; b) fasilitas pendukung, penambahan aquarium, koleksi artefak pada museum geologi, berbagai wahana permainan untuk anak-anak, spot foto, musala, papan informasi, dan mengecat ulang Jembatan Limpapeh; dan c) fasilitas penunjang, penambahan beberapa jalan setapak, kursi taman, tempat sampah, toko cendera mata, kursi gantung, dan loket. Kemudian Dispora juga melakukan pengecatan ulang pada kantor pegawai Taman Margasatwa dan Budaya Kinantan, perbaikan alat-alat sound system, dan pengembangan jaringan internet.

\section{Daftar Pustaka}

Badan Pusat Statistik Kota Bukittinggi. 2019. Kota Bukittinggi Dalam Angka, 2019. Badan Pusat Statistik Provinsi Sumatera Barat. 2019. Sumatera Barat Dalam Angka, 2019.

Dimahandi, Lalu Dwarno. 2017. Peran Pemerintah Desa Dalam Pengembangan Desa Wisata Sade (Studi pada Pemerintah Desa Rembitan Kabupaten Lombok Tengah). Sarjana thesis, Universitas Brawijaya.

Rosita, Marhanah, Wahadi, 2016. Pengaruh Fasilitas Wisata Dan Kualitas Pelayanan Terhadap Kepuasan Pengunjung Di Taman Margasatwa Ragunan Jakarta. Jurnal Manajemen Resort dan Leisure, Vol.3

Sugiyono (2015). Metode Penelitian Kombinasi (Mix Methods). Bandung: Alfabeta.

Yustinaningrum, Diah. 2017. Pengembangan Wisata Bahari Di Taman Wisata Perairan Pulau Pieh Dan Laut Sekitarnya. Agrika. Jurnal Ilmu-Ilmu Pertanian. Vol. 11. 